\title{
Land constraints and the modes of access to farmland in Benin: the case of the Couffo region in southwest Benin
}

\author{
Bernard FANGNON \\ Laboratory for the Study of Urban and Regional Dynamics (LEDUR), UAC, Tel. (229) 97099359
}

\begin{abstract}
This study has been conducted to assess the influence of land constraints on the modes of access to farmland in the Couffo Region.The work has been carried out by means of desk research, field surveys of farm operators, landowners, local elected representatives and officers of the Land Administration department. The surveys are based on samples collected at random and after thinking. The collection and the processing of data related to quantity and quality made it possible to come up with diagrams and tables containing a summary of findings.The data reveal that while people used to access farmland through inheritance and grants, nowadays they have access to it by purchasing, leasing or borrowing. This study draws the conclusion that landowners operate their own farming system and make investments on their farm when they inherit or purchase it. However, this is often limited by subsequent conflicts. $33 \%$ of land related disputes are due to purchased land, while $45 \%$ result from palm tree contracts (though this mode of access is disappearing). Most conflicts recorded in the tribunals are related to land. It is therefore pressing to take measures to secure tenure of land.
\end{abstract}

Key words: Couffo (Benin), constraints, land, access to land and operating mode.

\section{INTRODUCTION}

In underdeveloped countries in general and especially in African countries, land plays a great role in people's survival. As a cultural and sacred object as well as an element of social cohesion and an instrument of economic development, land is simply a very complex matter and an economic asset of paramount importance. Indeed, in both urban and rural areas, land is developed for purposes of housing, agriculture, animal husbandry, trade, industry, handicrafts, fish farming, etc. (Ouedraogo, 2009).In Benin, land is of paramount importance and has an economic, social and sacred dimension, etc. It is a factor of production for a large part of the population. The stakeholders have established very dense relations with regard to access to land and its management in local contexts which constantly highlight various strategies and practices and complex factors that interact due to the increasing number of issues at stake. (Koumassou, 2010). Access to land, its use and inheritance are governed by rules which vary from one socio-cultural group to another (Fangnon, 2012).The traditional rules of land attribution are unfavourable to agricultural women. As a matter of fact, in the Couffo region as well as in almost all other regions in Benin, traditions do not allow women to inherit land. Women's access to land has always been and is still a crucial problem. The management of land resources has always been one of the essential elements of community activities. Depending on the times and the political options, the management of land resources depends on political and cultural traditions. Some governments have adopted policies aiming to give men and women equal opportunities to access natural resources, especially land. However, the reality is quite different on the ground. Women continue to face all kinds of discrimination that keep them away from this valuable resource which is essential to ensure their empowerment and the socioeconomic development of their country. (Dimitra Project, 2008).In a context of sustained population growth, access to land, which is a vital ressource, becomes more and more difficult. Indeed, the growth of the rural population, which results in increasing demand for farmland, makes it complex to access land through traditional means (gifts and inheritance). The emergence of other modes of access to land, including purchase and rental, has given rise to many land disputes. The Couffo region (graphic 1) whose density was estimated at 309 inhabitants per square kilometer in 2013 compared to 218 inhabitants in 2002 (INSAE, RGPH3-4), is a region where the population density in rural areas is the highest in Benin. This increasing density puts pressure on farmland which is a valuable resource. 


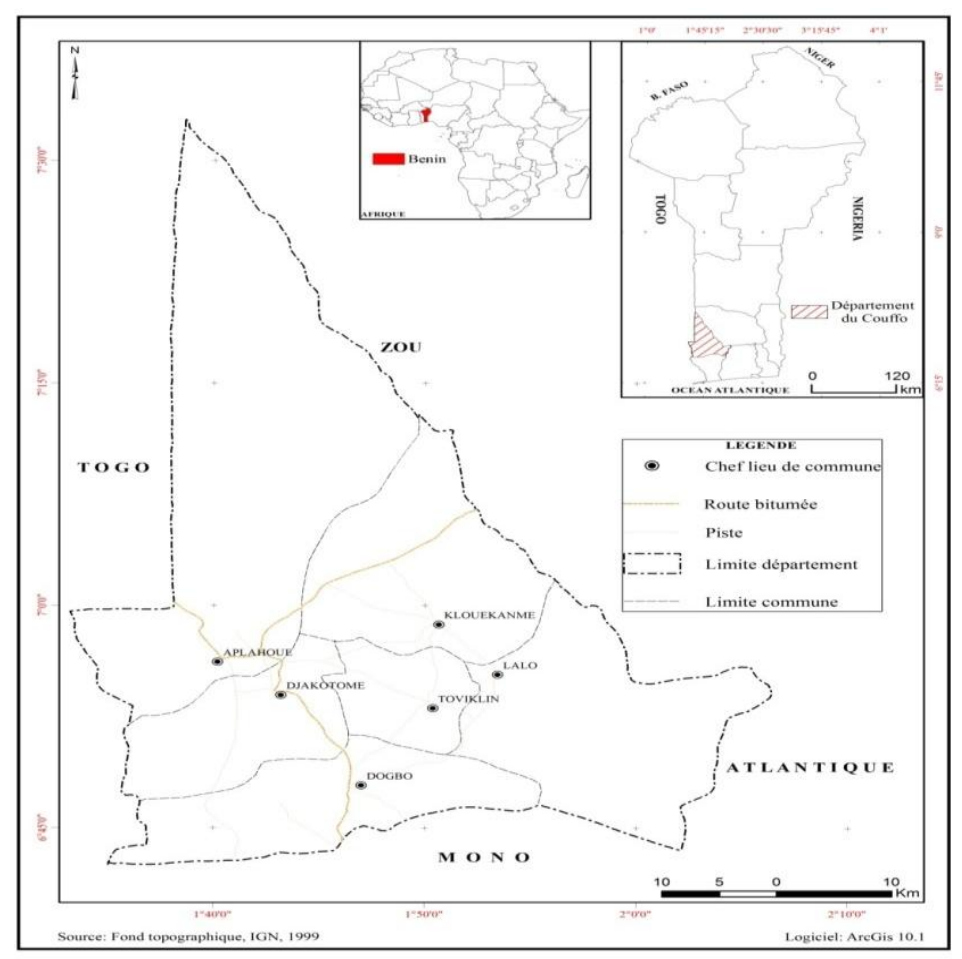

Graphic 1: Location of the area covered by this survey

\section{2- MATERIALS AND METHODS}

The data collected within the framework of this survey is related to the various modes of access to land and to land related conflicts. To this end, questionnaires, interview guides and observation grids were developed and used during the survey conducted with a sample of respondents.

\section{1- Sampling}

The target group comprises:

\subsection{1- Target group}

- farmers;

- farmers'associations;

- authorities at various levels;

- resource persons.

\subsection{2- Criteria used in selecting the respondents}

The method consisted in identifying a well-thought out sample of people to be interrogated within the framework of this survey and the number of farms to be visited.

The selection of respondents met the following criteria:

- To be a farmer and to have at least 15 years experience;

- To have at least one (1) farm;

- To work in a department that deals with agricultural issues.

The farms have been selected on the basis of their status (owner-operated farming system or farming system not operated by the owner). The samples are the six municipalities (Aplahoue, Djakotome, Dogbo, Klouekanme, Lalo and Toviklin) that the Couffo region is made up of.

\subsubsection{The size of the sample}

To determine the size of the sample, the formula of Schwartz (1995) has been used. Thus, if n denotes the size of the sample, we have:

$\mathrm{n}=\mathrm{Z} \alpha^{2} \times \mathrm{pq} / \mathrm{i}^{2}$

$\mathrm{Z} \alpha=$ reduced gap corresponding to a risk $\alpha$ of $5 \%$

$\mathrm{P}=$ proportion of agricultural households compared to the total number of households in the Couffo region (number of agricultural households $=61573$; total number of households $=97465$ ), therefore $p=63.17 \%$ 
$\mathrm{I}=$ desired accuracy is equal to $5 \%$

$\mathrm{Q}=1-\mathrm{p}$ (in this case, $\mathrm{q}=36.83 \%$ )

$\mathrm{n}=(1.96) 2 \times 0.6317(1-0,6317) / 0.052=357.5 \approx 358$ households

For the sake of efficiency, half or 179 households were involved in the survey.

The 179 households surveyed were scattered in administrative districts whose number varies from one municipality to another depending on agricultural production.

Table 1: Location of the people covered by the survey and the number of farms visited

\begin{tabular}{|l|lll|l|l|}
\hline Municipalities & $\begin{array}{l}\text { Total number of } \\
\text { agricultural } \\
\text { househlods }\end{array}$ & $\begin{array}{l}\text { Number } \\
\text { households } \\
\text { covered by }\end{array} \quad \begin{array}{l}\text { ofentage } \\
\text { the }\end{array}$ & $\begin{array}{l}\text { Number of farms } \\
\text { visited }\end{array}$ \\
\hline Aplahoué (4) & 14687 & 43 & 0.29 & 7 \\
\hline Djakotomè (2) & 10221 & 29 & 0.28 & 5 \\
\hline Dogbo (2) & 9196 & 27 & 0.29 & 4 \\
\hline Klouékanmè & 10264 & 30 & 0.29 & 7 \\
\hline Lalo (3) & 11076 & 32 & 0.29 & 4 \\
\hline Toviklin (2) & 6129 & 18 & 0.29 & 4 \\
\hline Region & $\mathbf{6 1 5 7 3}$ & $\mathbf{1 7 9}$ & $\mathbf{0 . 2 9}$ & $\mathbf{3 1}$ \\
\hline
\end{tabular}

Source: INSAE, 2013 and field work, 2014.

2.2- Collection and observation techniques

The collection started with the search for relevant documents and field work. To have a better understanding of the various modes of access to land, observations were made directly on the ground. The farms visited made it possible to note the farming systems.

\section{3- Statistical analysis of quantitative data}

The data collected is presented in graphics and tables. This helps to make comparisions, analyse and present the major trends.

\section{RESULTS AND DISCUSSION \\ 3.1- Results}

\subsection{1- Modes of access to farmland in the Couffo region}

As the main element of agricultural activity, land plays a basic role because no activity can be carried out without it. Access to land is linked to the social status of the family members or the individual (single, young household head, man or woman, etc.)

The various modes of access to land, which are known in the Couffo region, are: inheritance, unshared inheritance, purchase, borrowing, sharecropping, rental and palm tree contract.

\subsubsection{1- Inheritance}

Land inheritance is a transfer from one generation to another of land and its resources (Biaou, 1991). In the Couffo region, land inheritance is governed by a patrilineal system and only male children benefit from it. However, some parents (1\%) wishing to reward their daughters who have given birth to females only give land to these daughters when they are still alive. The land is often shared after the death of the father. While sharing the land, everybody is invited including neighbouring landowners. After the land is divided into plots, the beneficiaries are selected in order of age, i.e. from the eldest to the yougest children. The beneficiaries who are still minors are represented by their elder brother/sister born of the same mother.

Due to population growth, the portion of land allocated to each child becomes smaller and smaller. This situation is sometimes a source of disputes. According to some investigations, $48 \%$ of farm operators possess inherited land and can therefore carry out their activities on a sustainable basis. The average size of an inherited land is 19.2 ares, i.e. 4.8 bowo (note that there are nuances from one municipality to another) (table 2).

Table 2: Average size of the land inherited by each sex

\begin{tabular}{|l|l|l|l|}
\hline Municipalities & $\begin{array}{l}\text { Average size of land } \\
\text { inherited by both sexes } \\
(\mathbf{a})\end{array}$ & $\begin{array}{l}\text { Men's share } \\
(\boldsymbol{\%})\end{array}$ & $\begin{array}{l}\text { Women's share } \\
(\boldsymbol{\%})\end{array}$ \\
\hline Aplahoué & 20 & 95 & 5 \\
\hline Djakotomè & 8 & 98 & 2 \\
\hline
\end{tabular}




\begin{tabular}{|l|l|l|l|}
\hline Dogbo & 10 & 97 & 3 \\
\hline Klouékanmè & 9 & 94 & 6 \\
\hline Lalo & 12 & 90 & 10 \\
\hline Toviklin & 10 & 96 & 4 \\
\hline Region & $\mathbf{1 1 , 5}$ & $\mathbf{9 5}$ & $\mathbf{5}$ \\
\hline
\end{tabular}

Source : Field survey, 2014

A review of Table 2 reveals that women are not favoured in land distribution. Indeed, they do not inherit land because they are meant to join another family. However, a woman can inherit her mother's land. She can also inherit land if her family is made up of women only.

Further, the differences in the inherited land are due to the population density. The municipality of Aplahoue has a low density (297 inhabitants per sq. $\mathrm{km}$ ) compared to a regional average of 309 inhabitants per sq. $\mathrm{km}$. Some communities still have vast tracts of land. The unshared lands are also put to use.

\subsubsection{Unshared inheritance}

The unshared lands that are operated are those lands that belong to some people who have died but the Family Council has not taken the decision to share the lands among the beneficiaries. This mode of access is commonplace in monogamous families. It is a precarious mode of access that does not guarantee any property right. According to our survey, only 2 percent of farmers work on lands that have not been shared among brothers. When it is time to share the land, the beneficiaries are not sure that they will get back the cultivated land. That is why it is not safe to adopt this system of operation on a sustainable basis. This mode of access to land is disappearing in the region for two reasons: the first is that some old people demonstrate a sense of foresight by sharing the land during their lifetime; the second is that due to the increasing need for arable land, there is no time to waste and the land is shared after the funerals or at most one year later. Table 3 shows the average size of inherited and unshared land and the portion that the beneficiaries are entitled to on the basis of their sex.

Table 3 Average size of inherited and unshared land and percentage allocated to each sex

\begin{tabular}{|l|l|l|l|}
\hline Municipalities & $\begin{array}{l}\text { Average size of } \\
\text { inherited and unshared } \\
\text { land (a) }\end{array}$ & $\begin{array}{l}\text { Men's share } \\
(\boldsymbol{\%})\end{array}$ & $\begin{array}{l}\text { Women's share } \\
(\boldsymbol{\%})\end{array}$ \\
\hline Aplahoué & 20 & 95 & 5 \\
\hline Djakotomè & 8 & 98 & 2 \\
\hline Dogbo & 10 & 97 & 3 \\
\hline Klouékanmè & 9 & 94 & 6 \\
\hline Lalo & 12 & 90 & 10 \\
\hline Toviklin & 10 & 96 & 4 \\
\hline Region & $\mathbf{1 1 , 5}$ & $\mathbf{9 5}$ & $\mathbf{5}$ \\
\hline
\end{tabular}

Source : Field survey, 2014

A review of Table 3 shows that women have more access to unshared inherited land than to shared land. Indeed, after the death of the landowner, it may happen that his relatives, especially his sisters, ask for a plot of land that they start operating before the land is shared. Women in Lalo for example have more access to land through this mode than women in Djakotome where the pressure that is exerted on land would not enable men to let women operate a plot on a temporary basis before it is shared.

To circumvent the difficulties in accessing land, the people who have money increase the size of their property by purchasing more land.

\subsubsection{Purchase}

The mercantilist process of selling land started more than one century ago (Wartena, 1987). There are two categories of sellers: the conscientious and the non conscientious. According to the first category, land is a precious asset that can only be sold in case of force majeure (illness, death).

As to the second category, inherited land can be sold for reasons which are not really urgent. These include marrying another wife, performing funerals, etc. The buyer may pay in one instalment and get the sale agreement, or he may pay in several instalments. The prices range from CFA 35000 to CFA 65000 a "bowo" (400 sq. m), or from 875000 to 1625000 a hectare and it all depends on the location of the land from human settlements as well as on the quality of the soils (fertility for example).

The new buyers are often urban dwellers, traders and those engaged in land speculation. Field research shows that $18 \%$ of the farmers surveyed reported that they had bought farmland. On the purchased land, owners make 
investments without fear. Table 4 shows the average size of purchased land as well as men's and women's shares.

Tableau 4: Average size of land purchased and men's and women's shares

\begin{tabular}{|l|l|l|l|}
\hline Municipalities & $\begin{array}{l}\text { Average size of land } \\
\text { purchased (a) }\end{array}$ & Men's share (\%) & $\begin{array}{l}\text { Women's share } \\
(\%)\end{array}$ \\
\hline Aplahoué & 25 & 85 & 15 \\
\hline Djakotomè & 10 & 70 & 30 \\
\hline Dogbo & 15 & 75 & 25 \\
\hline Klouékanmè & 20 & 60 & 40 \\
\hline Lalo & 20 & 90 & 10 \\
\hline Toviklin & 10 & 80 & 20 \\
\hline Region & $\mathbf{1 6 , 7}$ & $\mathbf{7 6 , 6 7}$ & $\mathbf{2 3 , 3 3}$ \\
\hline
\end{tabular}

Source : Field survey, 2014

Table 4 reveals that the farmlands acquired in the Aplahoue municipality are bigger than those acquired in other municipalities. This situation is due to the low density. Among the buyers, there are fewer women because women are poorer than men in the region. However, it should be noted that the number of women buying plots of land is increasing in the Klouekanme municipality. This situation is due to the fact that female tomato producers' organisation is trying to put an end to the injustice resulting from the uneven distribution of land through purchase. To meet the need for agricultural land, some producers are compelled to borrow it.

\subsubsection{Borrowing}

Someone can borrow land free of charge. However, this is only pretence. As a matter of fact, the borrower is compelled to take care of the perennial crops (Palm trees, citrus fruit) for the landowner. This mode is current among members of a same family (including husband and wife) and is sometimes extended to friends. The landowner may at any time claim back his land even without giving any notice. The duration of this arrangement is often unspecified and the borrower does not have the right to turn the land into a plantation. He has to be very respectful towards his benefactor if he wants to keep the land for a long time. Among the farmers surveyed, $13 \%$ are working on borrowed land. Table 5 shows the average size of borrowed land and the shares of men and women.

Tableau 5: Average size of borrowed land and share of each sex

\begin{tabular}{|l|l|l|l|}
\hline Municipalities & $\begin{array}{l}\text { Average size of } \\
\text { borrowed lands (a) }\end{array}$ & $\begin{array}{l}\text { Men's share } \\
(\mathbf{\%})\end{array}$ & $\begin{array}{l}\text { Women's share } \\
(\boldsymbol{\%})\end{array}$ \\
\hline Aplahoué & 10 & 40 & 60 \\
\hline Djakotomè & 2 & 30 & 70 \\
\hline Dogbo & 4 & 45 & 55 \\
\hline Klouékanmè & 5 & 35 & 65 \\
\hline Lalo & 10 & 47 & 53 \\
\hline Toviklin & 3 & 33 & 67 \\
\hline Region & $\mathbf{5 , 7}$ & $\mathbf{3 8 , 3 3}$ & $\mathbf{6 1 , 6 7}$ \\
\hline
\end{tabular}

Source: Field survey, 2014

A review of table 5 reveals that borrowed lands are generally small but unlike the previously described modes, women borrow more lands. They argue that the exclusion they are the victims of compel them to do so. They said bitterly that some of the borrowed lands belong to their own deceased parents.

Given that land is borrowed among people who are familiar to each other, it does not enable all producers to access land and leads to sharecropping.

\subsubsection{5- Sharecropping}

Sharecropping is a farming contract in which the landowner leases out his rural estate for a specified period of time and shares its fruits and losses. Sharecropping in this area consists in dividing into three parts the yield. The landowner takes one third of the yield, while the farmer takes two-thirds. Therefore, it is a system of sharing, hence the name "dema" which literally means in Aja language "cultivate and share". This system is practised because of the difficulty in accessing land. Perennial crops always belong to the owner. Sometimes the latter thinks that the farm operator is not sharing the yield equitably with him and threatens to terminate the contract. It has been noticed that $5 \%$ of the surveyed farmers work on lands reserved for sharecropping. Table 6 shows the average size of lands reserved for share-cropping and the shares of men and women. 
Tableau 6: Average size of lands reserved for sharecropping and shares of men and women

\begin{tabular}{|l|l|l|l|}
\hline Municipalities & $\begin{array}{l}\text { Average size of } \\
\text { lands reserved for } \\
\text { sharecropping (a) }\end{array}$ & Men's share (\%) & $\begin{array}{l}\text { Women's share } \\
(\%)\end{array}$ \\
\hline Aplahoué & 15 & 99 & 1 \\
\hline Djakotomè & 5 & 95 & 5 \\
\hline Dogbo & 5 & 97 & 3 \\
\hline Klouékanmè & 5 & 98 & 2 \\
\hline Lalo & 10 & 99 & 1 \\
\hline Toviklin & 5 & 98 & 2 \\
\hline Region & $\mathbf{7 , 5}$ & $\mathbf{9 7 , 6 7}$ & $\mathbf{2 , 3 3}$ \\
\hline
\end{tabular}

Source : Field survey, 2014

It clear that Table 6 shows that the sizes of the lands reserved for sharecropping contract are small. There are not many women in this system. At Djakotome, the percentage exceeds that of other municipalities because some aged or sick landowners in search for rations prefer the farmers who agree to give them a share of the produce. Sharecropping is gradually disappearing and is being replaced by the rental of the lands.

\subsubsection{6- Rental}

There are three forms of land rental: the short one (1-3 years), the medium (5-10 years) and the longterm (over 10 years). Depending on the case, the rent is payable either annually or at the beginning of the contract. Rental costs vary depending on soil fertility. They vary between CFA 80,000 and 120000 per hectare for the medium term. The long term rental is disappearing. The short term rental is practised only in the areas like Djakotome where there are severere land constraints. At Djakotome, a plot of land rented is called "katchi" (plot of 400 sq. m) and the rental is annual. The tenant is not allowed to grow perennial crops. The risks related to the bad seasons are faced only by the tenant. The scarcity of farmland has contributed to the development of this mode of access to land. Table 7 shows the average sizes of rented lands and the shares of men and women.

Table 7: Average size of rented lands and shares of men and women

\begin{tabular}{|l|l|l|l|}
\hline Municipalities & $\begin{array}{l}\text { Average size of rented } \\
\text { lands (a) }\end{array}$ & Men's share (\%) & $\begin{array}{l}\text { Women's share } \\
(\%)\end{array}$ \\
\hline Aplahoué & 25 & 51 & 49 \\
\hline Djakotomè & 5 & 45 & 55 \\
\hline Dogbo & 10 & 48 & 52 \\
\hline Klouékanmè & 10 & 49 & 51 \\
\hline Lalo & 25 & 50 & 50 \\
\hline Toviklin & 10 & 47 & 53 \\
\hline Region & $\mathbf{1 4 , 2}$ & $\mathbf{4 8 , 3 3}$ & $\mathbf{5 1 , 6 7}$ \\
\hline
\end{tabular}

Source : Field surveys, 2014

An analysis of table 7 shows that the largest plots of land rented are at Aplahoué and Lalo (low density). More women work on rented land than men. However, it should be noted that some husbands (10\% of the sample) rent farmlands for their spouses, thereby respecting the tradition that compels men to "give" a plot of land to their wives for farming. In the Couffo region, when people fail to sell a plot of land, they put it in a system of palm tree contract.

\subsubsection{7- Palm tree contract}

In this system, palm trees are sold very early (when they are between 5 and 7 years). The buyer takes care of the Palm trees (collects the nuts to produce red oil above all) for about fifteen years. When the Palm trees are cut down, the contract ends. The expression that is used to refer to this system is "doude aso" which means in Aja language "eat the Palm tree and leave". However, when the buyer is the one who has to plant the Palm trees, the farming period becomes longer (between 20 and 25 years). In this case, the farming period is subdivided into three: - The farming period during which there are no Palm trees (1-2 years);

- The farming period during which there are Palm trees (6-10 years);

-The farming period of the Palm stand and the period during which the trees are felled (12 to 15 years).

To make the farming period shorter, the landowner puts pressure on the buyer so that: he can quickly plant Palm trees (and reduce the initial period), does not remove dead leaves (and shorten the second period) and does not take long to cut down the Palm trees (and reduce the third period). The long-term contract makes it possible to run a plantation from the beginning to the end.It has been noticed that this kind of contract is disappearing. This

DOI: 10.9790/0837-2109131119 www.iosrjournals.org $\quad 16 \mid$ Page


situation is due to land constraints, which cause palm trees to be cut down to make a room for seasonal crops, and to conflicts that occur sometimes after the death of the contracting parties. The last contracts are about to expire and concern only $1 \%$ of respondents. Table 8 shows the average size of the lands involved in palm contracts and the shares of men and women.

Table 8: Average size of lands involved in palm tree contracts and shares of men and women

\begin{tabular}{|l|l|l|l|}
\hline Municipalities & $\begin{array}{l}\text { Average size of lands } \\
\text { under palm tree contract } \\
(\mathbf{h a})\end{array}$ & Men's share (\%) & $\begin{array}{l}\text { Women's share } \\
(\%)\end{array}$ \\
\hline Aplahoué & 1 & 100 & 0 \\
\hline Djakotomè & 0,5 & 100 & 0 \\
\hline Dogbo & 0,5 & 100 & 0 \\
\hline Klouékanmè & 1 & 100 & 0 \\
\hline Lalo & 1 & 100 & 0 \\
\hline Toviklin & 0.5 & 100 & 0 \\
\hline Region & $\mathbf{0 . 7 5}$ & $\mathbf{1 0 0}$ & $\mathbf{0}$ \\
\hline
\end{tabular}

Source : Field survey, 2014

Table 8 shows that the sizes of the lands under palm tree contract are small. Women are not involved in this mode of access to land. Those who have money do it under the care of their male relatives.

In the Couffo region, inheritance was the only way of accessing land. However, with time other modes emerged. Today, a single producer can operate land obtained through different modes. Table 9 presents the modes of access to land in the region.

Table 9 : Modes of access to land

\begin{tabular}{|l|l|}
\hline Modes & Percentage (\%) \\
\hline Inheritance & 48 \\
\hline Unshared inheritance & 2 \\
\hline Purchase & 18 \\
\hline Borrowing & 13 \\
\hline Sharecropping & 5 \\
\hline Leasing & 13 \\
\hline Palm tree contract & 1 \\
\hline Total & 100 \\
\hline \multicolumn{2}{r}{ Source:Field survey, 2014 }
\end{tabular}

Inheritance is still the predominant mode of access to land even though the sizes of the lands are becoming smaller and smaller from one generation to another.The mode of access to land determines the production system (owner-operated farming system or farming system not operated by the owner). In the latter case, given that the right of use is precarious, there is no investment to restore or maintain soil fertility. Only inheritance and purchase make it possible to ensure a sustainable production system. The various modes of land acquisition lead sometimes to conflict.

\subsection{2- Land disputes}

Apart from inheritance which is shared in a sovereign way before all family members, other modes of access to land are contract-based. The oral nature of most contracts is often a source of land disputes. Even the contracts signed by the relevant authorities are challenged in court. Indeed, when an individual goes ahead to sell a plot of land in the absence of other beneficiaries, the latter rise up against the sale. In this region, there are plots of land that have remained fallow following court rulings. Table 10 shows dispute causing modes of access to land.

Table 10: Disputes due to the modes of access to land

\begin{tabular}{|l|l|}
\hline Modes & Disputes (\%) \\
\hline Inheritance & 1 \\
\hline Unshared inheritance & 1 \\
\hline Purchase & 33 \\
\hline
\end{tabular}




\begin{tabular}{|l|l|}
\hline Borrowing & 5 \\
\hline Sharecropping & 5 \\
\hline Rental & 10 \\
\hline Palm tree contract & 45 \\
\hline Total & 100 \\
\hline \multicolumn{2}{|l}{ Source : Field survey, 2014 }
\end{tabular}

Table 10 shows that conflicts are particularly related to purchased lands and palm tree contracts. The land constraint leads some children or grandchildren to question sales effected even before their birth. A 80-year old man narrated his misfortune in the following words: "I bought the plot that these children want to recover by force today when their late father wanted to pay the dowry to marry their mother."'Given that the palm tree contract is a long-term contract, when the landowner is in a hurry to recover his land or is in need of money, he takes the decision to sell the land under contract before the due date.In addition, conflicts with neighbours arise among farmers when neighbouring plants such as the Dracaena fragrans and the Jatropha curcas die or are cut maliciously.In a context of land constraints and conflicts arising in some areas, various cropping systems are adopted to operate farmlands.

\section{2- Discussions}

Modes of access (inheritance, borrowing, sharecropping and rental) to land in the Couffo region are in conformity with those found by Loconon (1987), Biaou (1991) and Honlonkou (1994). These authors had identified modes such as gift and pledge that have almost disappeared. Indeed, a pledge consists in ceding land for money, but unlike unlike purchase, the land is given back to the landowner as soon as he pays back to the creditor the amount of money collected from him. Population growth has put an end to this mode.Land borrowing is currently practised largely among relatives, especially spouses. According to Honlonkou (1994), farm operators' wives are above all those who benefit from this mode of access in the plateau of Aja. A husband is obliged by virtue of the customary marriage law to lend a plot of land to his wife. He is all the more obliged that there is no coincidence between the units of production, accumulation and consumption within the household.This mode is referred to as mixed (owner-operated farming system and farming system not operated by the owner) by Biaou. As far as we are concerned, it is a farming system that is not operated by the land owner. In a polygamous context, the arrival of a new wife can lead the former wife to cede one of the borrowed plots or to divide it if it's a single plot. Similarly, a daughter or a sister of the bridegroom who has returned home for one reason or another and who needs land, speaks to her father or brother who can take a part of a plot previously borrowed from his wife (or wives).The sharecropping known in the area under review is different from the land tenure system called "dimi-madimi" which is practised in Togo where the sharecropper, after a long time, eventually becomes owner of the land since the plantation is divided into two parts. There is one part for him and one part for the landowner (Badouin, 1985 quoted by Biaou, 1991).Moreover, the Ruthenberg coefficient $\mathrm{R}=86.36$ justifies the permanent agricultural system. This result is close to those of Honlonkou (1994) and Houngbo (2008) who found respectively $\mathrm{R}=75, \mathrm{R}=73$ in the same area. On the other hand, in 2005, Tente found in the Perma-Toucoutouna sector a coefficient of about 57.5. This value is higher than 33 but inferior to $66(33<\mathrm{R}<66)$, which leads to the conclusion that the fallow system is the one that is mostly practised on the ridges. In 2009, Wokou found that $\mathrm{R}$ was 10.12 . This value indicates that it is the mobile cultivation system on burnt-over areas which is mostly adopted by farmers in the Agonlin plateau.

The value $\mathrm{R}<33$ means that producers cultivate about one-third of the lands available. However, in the Couffo region, many producers operate $100 \%$ of the available land. The difference in the values of the Ruthenberg coefficient found by various researchers is due to the population density of each area.

\section{CONCLUSION}

Land is essentially a resource that cannot be expanded. The availability of farmland in the Couffo region where population growth is high proves to be particularly delicate. Access to land in the region is gained essentially through inheritance. The growing number of farmers is reducing the size of farm assets. When you operate a land which does not belong to you, you adopt precarious production systems. The various modes of access to farmland are becoming a source of conflict. The dynamics of the strategies of stakeholders competing for land influences its management and makes it more complex, and local communities (municipalities) find it difficult to own land management in a context characterised by population growth. The efforts that municipalities are currently making to subdivide land within the framework of the decentralization programme should be extended to agricultural land to ensure security of tenure. It is necessary that the Family Code is translated into concrete actions to enable women to have access to land in the same way as men with regard to the inheritance mode. 


\section{BIBLIOGRAPHICAL REFERENCES}

[1] Biaou G, (1991). Land tenure system and farm management in the Adja plateau in Benin. Doctorate thesis in Rural economics. Côte d'Ivoire: CIRES (Ivory Coast Economic and Social Research Centre), $207 \mathrm{p}$.

[2] Fangnon B, (2012). Soil quality and farming systems as well as environmental and socioeconomic impacts in the Couffo Region, South West of Benin. Doctorate Thesis in Geography, EDP/FLASH/UAC, $308 \mathrm{p}$.

[3] Honlonkou N A, (2008). Land pressure and agricultural loans in Benin. A comparative study of the cases of the Adja plateau and the Lonkly savana. Agronomist thesis. FSA, $197 \mathrm{p}$.

[4] Hougbo N E, (2008). Poverty dynamics and environment-friendly agricultural practices in rural areas in Africa. The case of the Adja plateau in the South of Benin. Doctorate thesis on environmental economics and sustainable development, EDP/FLASH/UAC, $309 \mathrm{p}$.

[5] INSAE (2013). Provisional outcomes of the fourth population and houses census. MDAEP, Cotonou, 8 p.

[6] Koumassou T, (2010). Stakeholders' stategies and land management by local governments: The case of the Kloukanme district. Master in Management science, $110 \mathrm{p}$.

[7] Loconon Z D, (1987). A socio-economic analysis of some farming systems within the framework of the development of a typology in the Adja plateau (Mono Region). A case study of three villages. Agronomist thesis, FSA, $131 \mathrm{p}$.

[8] Ouedraogo MB, (2009). Problems related to the access to land and land tenure security. The case of market gardening in Numa. Project work leading to the award of a diploma in counselling on land use planning and local development, pp. 2-10.

[9] DIMITRA PROJECT (2008). Women's access to land in West Africa: Problem areas and proposed solutions in Senegal and Burkina Faso, $52 \mathrm{p}$.

[10] Schwartz D, (1995). Statistical methods for medical doctors and biologists, 4th edition, Flammarion Medical issues, Paris, $314 \mathrm{p}$.

[11] Tente A B H, (2005). Research on factors of plant diversity in the versants of Atacora clump: PermaToucountouna area (Benin). Doctorate thesis in Geography, EDP/FLASH/UAC, 252 p.

[12] Wartena D, (1987). The development of the Adja economic system: Attitudes towards changes in the villages of Atindehouhoue and Housouhoue in the Toviklin district, Mono region, Benin. AbomeyCalavi: UNB/LUW/SVR project, $303 \mathrm{p}$. 